\title{
Entrepreneurship and marketing education: time for the road less travelled?
}

\author{
David Stokes* \\ Kingston University, \\ River House, Swan Wing, 53-57 High Street, \\ Kingston upon Thames, Surrey, KT1 1LQ, UK \\ E-mail: d.stokes@kingston.ac.uk \\ *Corresponding author
}

\section{Nicholas C. Wilson}

Kingston University, Kingston Hill, Kingston upon Thames, Surrey, KT2 7LB, UK

E-mail: n.wilson@kingston.ac.uk

\begin{abstract}
Three dimensions are proposed as a conceptual framework for entrepreneurship education: context, behaviours and process. Entrepreneurship educators have focussed more on the behaviours of entrepreneurs and less on the process of entrepreneurship. In doing so, they have also tended to avoid challenging the context of other disciplines such as marketing. If however we examine important aspects of marketing through the behaviours of entrepreneurs, we find that they do not conform to the standard concepts of marketing as portrayed in widely used learning materials. The increasingly well travelled 'pragmatic' road, which encourages the development of enterprising behaviours and skills, is contrasted with the less travelled 'conceptual' road, where our understanding of the phenomenon of entrepreneurship in contexts such as marketing, is challenged and explained. We suggest that unlike the poet's 'traveller' - who cannot take both roads, entrepreneurship education can benefit most by reaching the fork in the road and taking it.
\end{abstract}

Keywords: entrepreneurship; entrepreneurs; marketing; education; entrepreneurial marketing; word-of-mouth marketing; referrals.

Reference to this paper should be made as follows: Stokes, D. and Wilson, N.C. (xxxx) 'Entrepreneurship and marketing education: time for the road less travelled?', Int. J. Entrepreneurship and Innovation Management, Vol. X, No. Y, pp.000-000.

Biographical notes: David Stokes is Director of Enterprise and Innovation, and Associate Director of the Small Business Research Centre at Kingston University. He has published widely in the fields of entrepreneurship, small business management and entrepreneurial marketing, including the leading text Small Business Management and Entrepreneurship, currently in its 5th edition. His current research is investigating how entrepreneurial employees are recruited and retained by growing businesses. He is Chair of WestFocus, a consortium of seven universities in southwest London, and Chair of the Higher Education Entrepreneurship Group of SEEDA. 
Nick Wilson is Course Director of Kingston University's Programme of Masters courses in the Creative Economy, and Principal Lecturer in Entrepreneurship and Small Business Management. He has undertaken a range of research and consultancy projects focusing on the creative industries and the creative economy, including projects commissioned by the DCMS, Arts Council of England, and the LDA. His current research interests include developing critical realist theories of entrepreneurship, creativity, innovation and related social processes, and the development of multi-disciplinary learning in creativity and management.

\section{Introduction}

Entrepreneurship education has come a long way over the past decade or so. This paper explores this phenomenon, using the context of one other academic discipline marketing - to develop our understanding of where it might go in future. The almost ideological 'taken for granted' [Jack and Anderson, (1999), p.113] wisdom of the 'enterprise culture' (Keats and Abercrombie, 1991), has propelled the entrepreneurship agenda forward, alongside the increasing interest in the role of small businesses in the economy, itself a response to the rapidly changing political, social and economic environment at this time. During the late 1980s and throughout the 1990s, interest in small business management and entrepreneurship was reflected in a growing number of small business and new venture modules being developed across business schools around the world. Now, we are witnessing a real sea-change in the way in which entrepreneurship is embraced, not just in business schools but in and across universities as a whole. Broadly conceived as the introduction of new economic activity (Sarasvathy, 1999), entrepreneurship is no longer taught only in business schools or from enterprise centres. Entrepreneurship education is moving towards a mainstream concern for many, if not all faculties and departments in universities. While many universities have a lengthy history of publicly expressing support for entrepreneurship and the entrepreneurial agenda, this has not necessarily been evidenced in the implementation of concrete changes made to curricula and extra-curricular activities within and across the university (with some notable exceptions). Now that schools and departments within, and outside of the business school are buying into the entrepreneurship agenda, there is an understandable concern on behalf of educators from other disciplines to know exactly what it is all about. Not surprisingly, they look to those working directly in the field of entrepreneurship for theoretical and pedagogical re-assurance. For their part, entrepreneurship educators have an obligation to swell student numbers and be seen to be making in-roads in terms of the depth and breadth of their activities across the university. Under these conditions one might suggest that the 'march' of entrepreneurship will head towards relatively safe territory, such as the 'pragmatic' pursuit and development of enterprising behaviours, rather than towards more controversial areas where difficult questions about the phenomenon of entrepreneurship itself are raised.

In the UK, the changes that have taken place over the last decade have much to do with 'top-down' funding and initiatives such as the science enterprise challenge fund and higher education innovation fund (rounds 1, 2, 3 and now 4) and the broader policy interest in entrepreneurship and related concepts (see, for example, European Commission Paper (2003), DTI Innovation Report (2003), Cox Review of Creativity in 
Business (2005); establishment of National Council for Graduate Entrepreneurship (see NCGE, 2006; Harding, 2006, 2005). As we begin to see the fruits of new programmes of top-down funded entrepreneurship education, we can see the even more exciting potential and knock-on effects of 'bottom-up' developments. Certainly, one of the most powerful sources of evidence to justify entrepreneurship education comes from the successful exploits of the student body itself. The enthusiasm and creativity of students represents a tangible source of inspiration both for their student peers and for those involved in entrepreneurship education. This, of course, is essential if the developments we are enjoying today are to become embedded and sustainable in the higher education (HE) infrastructure.

Despite apparent success, there remain many questions over how we will assess the impact of the entrepreneurship education that is now spreading through other disciplines, faculties and schools. In particular, the relationship of entrepreneurship to other established academic disciplines becomes significant in determining how it is to be embedded within the curriculum. Can entrepreneurship be considered in isolation or does it need a context in order to fully explain its effects? For example, marketing and entrepreneurship have existed within business schools and elsewhere as two independent domains of scholarship. There is increasing evidence of overlap in the topics that both might cover including creativity and innovation, new product development and customer communications. The interface between marketing and entrepreneurship has encouraged the notion of 'entrepreneurial marketing' to be developed as an alternative to 'traditional' or 'classic' marketing (Carter and Jones-Evans, 2006). Is this a real distinction that will stand the test of time or an artificial one that is promoted by the entrepreneurship bandwagon? To consider this question we need first to understand more of the conceptual foundations of entrepreneurship and secondly to examine if entrepreneurial marketing is indeed different to the marketing that is encapsulated in standard marketing text books.

\section{Conceptualising entrepreneurship}

Despite the crescendo of scholarly research and academic interest in entrepreneurship over recent years, there remains the challenge of identifying a truly coherent and convincing conceptual framework for this phenomenon. Entrepreneurship has become an omnibus word [Jack and Anderson, (1999), p.115]. To borrow an expression from Eagleton (1991), 'it has become a text, woven from a tissue of conceptual strands'. There remains much that we do not really understand about entrepreneurship and the need for a clearer conceptualisation has been made by many commentators (see Gartner, 2001; Zahra and Dess, 2001; Davidsson et al., 2001; Davidsson, 2003; Gibb, 2005).

There have been significant advances in our understanding, most notably in the linking of entrepreneurship with opportunity identification and exploitation (Venkataraman, 1997; Shane and Venkataraman, 2000; Eckhardt and Shane, 2003; Shane, 2003). Notwithstanding the breadth and depth of contributions in this field that take different theoretical perspectives, foci and levels of analysis (Low and MacMillan, 1988), we remain in search of a distinctive conceptualisation of entrepreneurship (Phan, 2004). Nowhere is this search more important than in the field of education where, in order to establish its place in relation to other academic disciplines such as marketing, 
'the need for a clarification of the concept of entrepreneurship is paramount' [Gibb, (2005), p.2].

One of the barriers to achieving this clarification is the wide variety of different theoretical perspectives or vantage points from which entrepreneurship is discussed (Lawson, 1997) - including the context of marketing, which is the subject of this paper. Students, educators, researchers, practitioners, policy-makers and investors, all hold different perspectives on entrepreneurship. Their understanding of the concept is necessarily related to their personal or professional goals and objectives. These relate in some form to three main theoretical perspectives, or schools of thought: the economic functional perspective, personality perspective and the behavioural perspective (Stevenson and Sahlman, 1989; Cope, 2005). Stakeholders' understanding of the concept is necessarily related to their personal or professional goals and objectives. Many students, for example, see entrepreneurship as being either something to do with setting up a business, or indicating some special attributes of the 'heroic' entrepreneur, popularly personified in individuals such as Alan Sugar, Richard Branson, James Dyson and Anita Roddick. Despite the 'opening-up' of universities to the entrepreneurship agenda, many academics still see entrepreneurship as a rather faddish sub-discipline of business schools - and are wary of it. Definitions of entrepreneurship, therefore, can be seen to differ along a number of related dimensions - dispositions, behaviours or outcomes [see Davidsson, (2003), pp.2-3].

Having correctly embraced this epistemological relativism, some entrepreneurship commentators go on to make the incorrect assumption that complexity and theoretical confusion necessarily go hand in hand. Gartner (2001, p.34) states explicitly that 'the various topics in the entrepreneurship field do not constitute a congruous whole'. This conclusion is reached on the grounds that the 'totality of current academic entrepreneurship research does not espouse (nor can it espouse) an entrepreneurship theory, per se' (p.34). However, to move on from this point and claim that there is no one 'object' to study (as Gartner does) effectively reduces statements about being, to statements about knowledge. This perspective carries with it the danger that 'epistemological considerations about how knowledge is constituted are used to define what exists and how it can be known' [Cruickshank, (2003), p.5].

The crux of the matter is that while many entrepreneurship (and marketing) researchers follow the traditionally positivistic approach of traditional management research, entrepreneurship (and entrepreneurial marketing) is 'anti-positivistic' in that causal laws of phenomena cannot be derived from observation alone (Johannisson, 1992). The prevailing empirical realist perspective to the study of entrepreneurship and its contexts encourages the separate accumulation of partial theories (Fiet, 2000) and chaotic conceptions [Marx, (1973), p.100] about entrepreneurship and related areas such as entrepreneurial marketing (see Vesper, 2004; Steyaert and Hjorth, 2003). This 'horses for courses' approach is further perpetuated by the predominantly pragmatist, agential vein that runs through entrepreneurship education. The educational focus is primarily on developing those (entrepreneurial) behaviours that are widely held to facilitate successful new venture creation or innovation. There is both an irony and a paradox here. At face value, at least, entrepreneurship education has a tendency towards certainties rather than a tolerance of uncertainty. As previously indicated, the need for the entrepreneurship educator to pin down entrepreneurship as being ' $x$ ' or ' $y$ ' has become ever more pressing as interest in it has spread first across the business school, and then the university as a whole. If, as Gibb (2005) suggests, entrepreneurship is about coping with uncertainty and 
complexity, then entrepreneurship education could well be seen as increasingly lacking in these entrepreneurial attributes. In fact, this misrepresents what is probably the most pressing conceptual problem for entrepreneurship education today, namely the lack of attention given to the ontological distinction between entrepreneurship and other related concepts - e.g. the entrepreneur; entrepreneurial firm; entrepreneurial behaviours etc. It is not simply that these different terms represent different discourses around the area of entrepreneurship. They refer to ontologically distinct entities in the material world. An entrepreneur is an agent constituted by an individual human being. As we have noted, human beings have behaviours, attributes and skills which can be developed through learning (i.e. entrepreneurial education). However, entrepreneurship - as 'the introduction of new economic activity' (Sarasvathy, 1999), or 'the creation of new organisations to create and extract value' (Jack and Anderson, 1999) - involves both agential actions and social structures in the relations between agents. These social 'processes' cannot be reduced to human behaviour alone (i.e. the voluntarist position is untenable). Although pragmatic and agential models of entrepreneurship education are appealing, they are only part of the story. Entrepreneurship and entrepreneur are used interchangeably and they are, of course, inseparable concepts. However, they are also concerned with fundamentally different aspects of a phenomenon. When we talk about entrepreneurs, we are usually interested in their particular behaviours, attributes and skills [for a helpful summary of these, see Gibb, (2005), p.37]. When we talk about entrepreneurship we have a process in mind such as the introduction of new economic activity. In both cases, we will also be framing our conceptualisation within a given context (e.g. setting up a new venture, or introducing innovation into an established firm). This is particularly relevant when we consider contexts such as 'entrepreneurial marketing'. This is used to describe and delineate both particular behaviours (i.e. marketing as practiced by entrepreneurs), and processes (i.e. the interface between the processes of entrepreneurship and marketing). We will return to the relevance of behaviours, process and context in the next section of the paper.

\section{A conceptual framework for approaches to entrepreneurship education}

In the light of the comments made so far about the need for ontological clarity in distinguishing between related aspects of entrepreneurship, we might then reasonably focus attention on the question of what entrepreneurship education is (or ought to be) about. If the phenomenon of entrepreneurship (as a particular process of social change) sits at the heart of education, then students need to develop learning about this particular process and be able to relate it to other fields that they are studying, such as marketing (or non-business subjects such as IT, bio-science etc. in which entrepreneurial processes have become common). If, on the other hand, the entrepreneur is at the heart of education, then students need to focus on developing their learning about and application of 'entrepreneurial behaviours', and be able to relate those to the different economic and social contexts of their studies. Of course, both perspectives are relevant - as the one (the process) demands attention to the other (the behaviours). However, it will depend upon the particular vantage point of those involved in entrepreneurship education as to where the primary focus might lie. This, in turn, will call for different programmes of 
entrepreneurship education that seek to engage students in different activities with different outcomes.

We can frame the likely different approaches to entrepreneurship education in terms of three 'dimensions' - behaviours, context and process (see Figure 1).

Figure 1 The three dimensions of entrepreneurship education

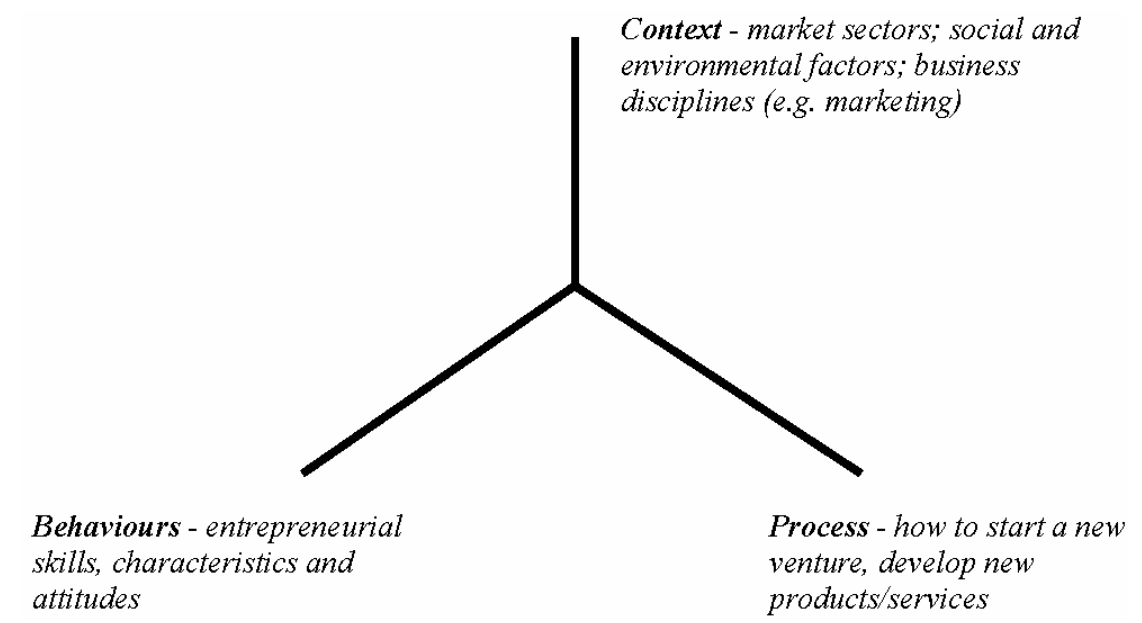

Entrepreneurship education is interested in all three dimensions. In the UK, at least, we suggest that the focus on entrepreneurial behaviours is very much in the ascendancy, as this sense of self-discovery and behavioural independence sits very comfortably with popular notions of what being entrepreneurial, or enterprising, is all about. It endorses the view of 'peoplism' that the most important driver of value creation is the enterprise and creativity of individuals, 'assets which only the individuals themselves can own' [Horne, (2000), p.10]. It also resonates with the proactive, risk-taking image of the entrepreneur that has established the centre ground in our public consciousness. Fear of failure still represents the single largest barrier to entrepreneurship for men and women in the UK [Harding, (2005), p.11], suggesting that non-entrepreneurs are more passive and risk adverse. Nascent entrepreneurs are usually eager to know more about what constitutes these differences with a view to replicating successful entrepreneurial characteristics. These are often demonstrated through the use of positive role models and exemplars to undergraduates who are being encouraged to consider setting up a business as a career option (NCGE, 2005). Although somewhat dismissed in terms of its limited contribution, entrepreneurial trait theory still holds a deep fascination for the student of entrepreneurship. 'Are entrepreneurs born or made?' is a question that every entrepreneurship student can relate to - or replace with: 'do I have what it takes?'

In his paper 'Towards the entrepreneurial university' (2005), Allan Gibb replaces the 'dominant model of the entrepreneur', which he describes as a 'Frankensteinian' (p.17) creation born out of corporate business concerns, with an 'alternate' model that has entrepreneurial values at its heart. These values are associated with 'the ways of doing things, organising things, feeling things, communicating things, understanding and thinking things, and learning things' (p.19). They include such values as a strong sense of independence; strong sense of ownership; belief that rewards come with own effort; belief in being able to make things happen [for a full list see Gibb, (2005), p.40]. Clearly 
then, according to Gibb, an 'appropriate' model for entrepreneurial teaching is an overtly agential model - focusing squarely on the individual and his/her abilities, skills and behaviours.

Of course, the development of entrepreneurial behaviours (as outlined above) is a desirable outcome regardless of whether individuals actually pursue entrepreneurship in terms of new venture creation. There is a strong case to suggest that the key skills framework that underpins higher education learning and teaching should be developed to embrace entrepreneurial skills at a foundation level. This stands in contrast, however, to the specifics of the context and process dimensions of entrepreneurship education which tend to be seen as:

1 the domain of small business education (see Gibb, 1993, 1994, 2000)

2 the domain of for-profit business education - where individual wealth creation is emphasised

3 contingent on specific contexts (e.g. business disciplines including marketing, biotechnology, IT, engineering, film and media) and therefore beyond many of the general programmes which focus on the development of enterprising and entrepreneurial behaviours.

The 'context' for entrepreneurship education has, of course, become increasingly differentiated. Specialised accounts use variables as diverse as: gender, family and ethnicity (Carter and Jones-Evans, 2006); market sectors such as technology-based firms (Oakey, 1994); 'green' entrepreneurship and the development of 'ecopreneurship' (Schaper, 2002); and cultural entrepreneurship (Leadbeater and Oakley, 1999; Fillis and McAuley, 2000; Brindley, 2000; Ellmeier, 2003; Wilson and Stokes, 2005). We can also point to an increasing interest in international entrepreneurship in the sense of understanding the different economic and socio-cultural conditions that impact entrepreneurship as it is carried out across the world (see, for example, Bannock, 2005; Begley and Tan, 2001) in an increasingly competitive environment.

The process dimension has centred around the development of a new business or innovation strategy and the writing of a business plan, activities that are sometimes viewed as surrogate for the entrepreneurship process itself. This confuses the micro level, 'agential' processes of entrepreneurial activities (i.e. the nuts and bolts practices carried out by individual entrepreneurs and intrapreneurs) with the 'structural' process at the level of societal change. Entrepreneurship education needs to provide understanding and explanation of the mechanisms through which entrepreneurship acts as a source of benefit to society - either through new economic or social activity.

\section{Entrepreneurial marketing}

What, then of entrepreneurial marketing? As we have discussed, marketing is not alone in the field of education as an academic context in which entrepreneurship can become manifest. There are now many courses that link entrepreneurship to other disciplines including IT, engineering, bio-science and environmental science (NCGE, 2005). Marketing was, however, one of the first in which strong linkages were established. For example, a special interest group in the marketing and entrepreneurship interface was set 
up by the UK Academy of Marketing in 1995 (Day, 1998). If we adopt the model of entrepreneurship education proposed above, we should consider the relevance of entrepreneurial marketing by considering the behaviours of entrepreneurs when they undertake marketing activities, as well as comparing and contrasting the processes of marketing and entrepreneurship. If we can understand if entrepreneurs act differently to other managers when they undertake marketing activities, it would suggest there is some justification for the study of 'entrepreneurial marketing' as a distinctive aspect of marketing and a distinct context for entrepreneurial processes.

Like entrepreneurship, marketing also has its problems of definition. Marketing can be considered on several distinct organisational levels: cultural, strategic and tactical (Webster, 1995). First, at the cultural and strategic level, marketing has been proposed as 'business philosophy' that guides strategic decision making. The marketing concept of customer orientation represents a way of doing business, with the needs of the customer held as central tenant of an enterprise that ought to be considered at every level. The process of entrepreneurship can also be considered as an over-arching imperative that is central to the philosophy that guides all the activities of an enterprise (Kirby, 2003). Do these two strategic behavioural models conflict with, or complement, each other? In one important respect, they may be in conflict. Decision making is key management behaviour (Johnson and Scholes, 2002). Following the marketing concept, decisions need to be made in the full knowledge of customers needs. If the organisation is adopting a strategy that is customer oriented, decisions have to revolve around what is best for the customer providing they are not in conflict with organisational survival. Entrepreneurial behaviour is characterised by heuristic decision making, or relying on intuition - the gut feel of the entrepreneur (Busenitz and Barney, 1997). This may coincide with the notion of customer orientation if the entrepreneur can always truly put themselves in the position of the customer and feel empathy with them. A characteristic of many successful entrepreneurs is that they do have an intuitive feel for what their customers want, an antenna into the market place that never fails them (Granoveter, 1973). However, many entrepreneurs have shown that their intuition is not always a reliable indicator of customer demand. The ability to make rapid changes to what they do is also a key characteristic of successful entrepreneurs partly because they do misunderstand the nature of the market place and therefore have to make rapid adjustments to compensate for misjudgements of customer needs and other decisions (Storey, 1998). In this sense, 'entrepreneurial marketing' does differ from the classic marketing concept in that entrepreneurs tend to understand customer needs by intuition, and then trial and error if they get it wrong. Marketing text books promote the cause of formalised methods, including marketing information systems and research, as a more rigorous way of staying in touch with the market (e.g. Kotler, 2003).

At a second level of meaning, marketing can be considered as a series of tactical activities that take products and services into the market place and into the hands of appropriate buyers (Webster, 1995). Perhaps the most important of these activities is acquiring customers, as the many chapters on marketing communications and related topics in most text books illustrate. Research into the behaviour of entrepreneurs running small businesses, indicates a strong preference for one method over all others in how they attract customers. Recommendations and word-of-mouth referrals is the most popular method in virtually all sectors and sizes of SMEs (Barclays Review, 1997; Stokes and Wilson, 2006). One study of 300+ owner-managers (Stokes et al., 1997) found that over $90 \%$ of owner-managers of small businesses used word-of-mouth communications as 
their primary way of transmitting marketing messages. Recommendations from existing customers were the most frequently claimed type of promotional activity. Moreover, the second most popular method of customer acquisition was recommendations from other sources (i.e. non-customers). This is not just life-style owner-managers who have little ambition to grow. In a more recent study (of established small firms of more than five employees), nearly two thirds of the companies identified as high growth claimed recommendations to be the most effective way of attracting customers (Blackburn and Stokes, 2003). Entrepreneurs seem to prefer direct interaction with their client base as face-to-face selling is often the next preferred method of customer acquisition to word-of-mouth. The increasing use of the internet by entrepreneurs has not changed this (Chaffey et al., 2006), and in fact may have increased the usage of recommendations as the internet has become a huge source of referral for products and services especially since the advent of 'web 2.0' that invites participation from internet users. Most internet retail sites ask for customer comments on the products and services they sell which stand as recommendations to potential customers (e.g. Amazon.com) - an opportunity for the entrepreneurial seller to encourage favourable postings.

However, word-of-mouth and recommendations are not considered in any detail in the major text books on marketing. A review of the contents of the frequently used US and UK undergraduate and postgraduate marketing text books (e.g. Brassington and Pettitt, 2006; Jobber, 2006; Kotler, 2003) reveals that they have little to say about the most common method of customer acquisition used by entrepreneurs. 'Word-of-mouth marketing', 'referrals' and 'recommendations' generally feature in two of the chapters of such standard marketing text books. First, the role of recommendations is mentioned as part of buyer behaviour models particularly in the importance of opinion leaders and the need for re-assurance in the pre-purchase phase. Secondly, the importance of word-of-mouth communications is mentioned in the chapters on marketing communications with reference to the power of word-of-mouth as an uncontrollable, positive or negative communication. Apart from in these two areas, this vital marketing tool for entrepreneurs is hardly discussed further. Even in these sections where it is raised the topic does not get much coverage, often less than one page in texts of 700 or 800 pages. The discussions on word-of-mouth total about one page of the 718 pages in Kotler (2003); Brassington and Pettitt (2006) run to a few paragraphs in over 1000 pages, with no listing of word-of-mouth in the glossary or index. Practitioner rather than student focussed advice also has little to say on the topic. Of the 28 courses advertised by the Chartered Institute of Marketing (cim.co.uk) on marketing communications, none of them major on word-of-mouth. Business link have a 'benchmark index' that claims to be an 'extensive benchmarking resource for small business' (businesslink.gov.uk). However the questionnaire and notes that create the input for the process contain no mention of word-of-mouth or stimulating recommendations or referrals.

It would seem therefore that, there is a mismatch between what entrepreneurs actually do in order to acquire customers and the activities described in major marketing text books and training materials. This would at least seem to substantiate the need to differentiate between 'entrepreneurial marketing' behaviours and traditional or classic marketing behaviours. It is possible that entrepreneurs are behaving as a disruptive influence in this particular business discipline, challenging the status quo of marketing behaviour in a way that followers of Schumpeter would expect entrepreneurs to behave. Almost certainly, entrepreneurs have developed an alternative style of marketing to that 
carried on traditionally by larger firms (Stokes, 2000), so that the processes of marketing in entrepreneurial firms are also different.

The problem is that although owners claim to use word-of-mouth to communicate with customers, they know little in practice about what is actually happening in their communications with customers. Although they know their customers come in the first place by referrals and recommendations, they know little of the processes by which these referrals take place. For example, when asked exactly which customers are generating referrals, many owner managers will answer that it is their 'best customers' that refer the most by which they often mean the most loyal and long serving customers (Stokes et al., 2002). Although this appears logical and the accepted wisdom of many business owners, it is often the opposite that is more accurate. A number of studies (e.g. East et al., 2000) have shown that it is the most recent customers that refer most frequently; they are enthused by positive recent experiences that they are keen to share with friends. Thus, it is 'stories' that make recommendations and more recent experiences tend to be the stories that we pass on the most.

\section{The path well- or less-travelled?}

Thus, entrepreneurship education has reached a fork in the road especially in its relationship to the marketing discipline. In reaching out into many academic areas, the process of entrepreneurship and the practice of entrepreneurs do not necessarily conform to the well-rehearsed theories and pedagogic frameworks used by educators. Entrepreneurs cannot be taught the theory of marketing by reference to the current paradigms, it would seem, as these lack pragmatic application to the context of entrepreneurship. This may apply to other academic fields. If we need to develop 'entrepreneurial marketing' theory, do we also need to consider 'entrepreneurial innovation' by studying in greater depth how technical entrepreneurs go about their discoveries? Are their theories of 'entrepreneurial accounting' to be discovered from the study of how successful entrepreneurs manage their finances that could challenge the accepted notions?

Taking these issues into account, it would seem that the role of entrepreneurship within contexts of education such as marketing has come to something of a fork in the road, rather like the traveller in Robert Frost's famous poem 'The Road Not Taken' (see Appendix), and educators now need to decide which way to continue their journey.

In the imagery of Frost's enigmatic and deliberately ambiguous poem, we can choose to take the increasingly well travelled 'pragmatic' road, that develops entrepreneurial skills in parallel to other disciplines that students are studying without challenging the fundamentals of those disciplines. Or we can take the 'conceptual' road less travelled along which the processes of entrepreneurship and the behaviours of entrepreneurs are allowed to increasingly challenge the context in which entrepreneurship is applied. Down the pragmatic road, the primary focus is on teaching and learning that develops entrepreneurial or enterprising behaviours, skills and attributes in individuals whilst applying standard paradigms of business strategy and marketing. The teaching of business planning would be an excellent example here. Research indicates that entrepreneurs make decisions in different ways to other managers, relying on intuition and biases more than formal market data (Busenitz and Barney, 1997). This often leads to a lack of formalised planning by entrepreneurs (Hills and Hultman, 2005) who often do 
not produce a formalised business plan when they start up except maybe to please the bank. But almost every entrepreneurship course insists that business plans are produced as an integral part of the learning process. Along the conceptual road, attention is placed on developing a better conceptualisation through appropriate research of the phenomenon of 'entrepreneurship' in specific contexts such as marketing. The essence of this strategic challenge is to provide a balanced view of entrepreneurship, that is, perhaps as bold about what we don't know about the phenomenon as what we do know. Although we do know that pro-active, enterprising behaviours are a necessary condition of successful entrepreneurship, we do not know about many aspects of causality and the impact of entrepreneurial education.

As an undertaking that often finds itself outside of its academic roots, entrepreneurship education still needs research to underpin the teaching and delivery of courses and programmes. This is not easy. Entrepreneurship and enterprise has become the fastest growing discipline in many universities around the world (Frederick, 2005). There is a shortage of entrepreneurship educators as the student numbers swell. Such circumstances are likely to favour the pragmatic approach that can deliver accepted messages effectively to large audiences. It is tempting to only deliver 'how-to' programmes and not ask the more difficult questions of 'why?' and 'with what long term impact?'

In an ideal world, the three university missions of teaching, research and enterprise should link in a 'virtuous circle' so that one activity supports and is informed by the others. Gibb (1993) and others have long argued that entrepreneurship education should be taken out of the business school context so that it can become embedded in other disciplines and throughout all schools and faculties. The location of entrepreneurship in central enterprise units may have helped to make it a more universal offering but it has also cut it off from a natural research base. The conceptual route has become barred to many entrepreneurship educators operating in central enterprise units through shortage of resources and funds, and possibly lack of tradition and interest in research. Having reached the fork in the road, the traveller wearing the entrepreneurship educator's hat can benefit most by taking it.

\section{References}

Bannock, G. (2005) The Economics and Management of Small Business: An International Perspective, Routledge, London.

Barclays Review (1997) Marketing and the Small Firm, May, Barclays Bank Plc., London.

Begley, T.M. and Tan, W. (2001) 'The socio-cultural environment for entrepreneurship: a comparison between East Asian and Anglo-Saxon countries', Journal of International Business Studies, Washington, Sept., Vol. 32, No. 3.

Blackburn, R. and Stokes, D. (2003) Who are the Entrepreneurs? A Survey of the Owners of Small and Medium Sized Enterprises, Report to Kingston Smith, September, SBRC, Kingston upon Thames: Kingston University.

Brassington, F. and Pettitt, S. (2006) Principles of Marketing, 4th ed., Pearson Education, Harlow.

Brindley, P. (2000) New Musical Entrepreneurs, IPPR, London.

Busenitz, L.W. and Barney, J.B. (1997) 'Differences between entrepreneurs and managers in small firms: biases and heuristics in strategic decision-making', Journal of Business Venturing, Vol. 12, pp.9-30. 
Carter, S. and Jones-Evans, D. (2006) Enterprise and Small Business: Principles, Practice and Policy, 2nd ed., FT Prentice Hall, London.

Chaffey, D., Mayer, R., Johnston, K. and Ellis-Chadwick, F. (2006) Internet Marketing, Pearson Education, Harlow.

Cope, J. (2005) 'Toward a dynamic learning perspective of entrepreneurship', Entrepreneurship Theory and Practice, July, pp.373-397.

Cox, G. (2005) Cox Review of Creativity in Business: Building on the UK's Strengths, Design Council, London.

Cruickshank, J. (2003) Realism and Sociology: Anti-foundationalism, Ontology and Social Research, Routledge, London.

Davidsson, P. (2003) 'The domain of entrepreneurship research: some suggestions', in. J. Katz and S. Shepherd (Eds.): Advances in Entrepreneurship, Firm Emergence and Growth, Oxford: Elsevier/JAI Press, Vol. 6, pp.15-372.

Davidsson, P., Low, M.B. and Wright, M. (2001) 'Editor's introduction: low and MacMillan ten years on: achievements and future directions for entrepreneurship research', Entrepreneurship Theory and Practice, Summer.

Day, J. (1998) 'Defining the interface: a useful framework', in Hulbert, Day and Shaw (Eds.): Proceedings of the Academy of Marketing Symposia on the Marketing and Entrepreneurship Interface: 1996-1998, Nene University College, Northampton.

DTI (2003) Innovation Report: Competing in the Global Economy: The Innovation Challenge, December, DTI, London.

Eagleton, T. (1991) Ideology, Verso, London.

East, R., Lomax, W. and Narain, R. (2000) 'Customer tenure, recommendation and switching', Kingston Business School Occasional Papers, Kingston upon Thames: Kingston University.

Eckhardt, J.T. and Shane, S.A. (2003) 'Opportunities and entrepreneurship', Journal of Management, Vol.29, No. 3, pp.333-349.

Ellmeier, A. (2003) 'Cultural entrepreneurialism: on the changing relationship between the arts, culture and employment', The International Journal of Cultural Policy, Vol. 9, No. 1, pp.3-16.

European Commission (2003) Green Paper: Entrepreneurship in Europe, Brussels, 21st March.

Fiet, J.O. (2000) 'The theoretical side of teaching entrepreneurship', Journal of Business Venturing, Vol. 16, pp.1-24.

Fillis, I. and McAuley, A. (2000) 'Modelling and measuring creativity at the interface', Journal of Marketing Theory and Practice, Vol. 8, No. 2, pp.8-17.

Frederick, H. (2005) 'Educating generation-e in Australasia: US lessons, New Zealand experience', Proceedings of the Internationalizing Entrepreneurship Education and Training (Int. Ent.) Conference, July, University of Surrey, Guildford.

Gartner, W.B. (2001) 'Is there an elephant in entrepreneurship? Blind assumptions in theory development', Entrepreneurship Theory and Practice, Vol. 25, No. 4.

Gibb, A.A. (1993) 'The enterprise culture and education: understanding enterprise education and its links with small business, entrepreneurship and wider educational goals', International Small Business Journal, April/June, Vol. 11, No. 3.

Gibb, A.A. (1994) 'Do we really teach small business the way we should', Journal of Small Business and Entrepreneurship, January/March, Vol. 11, No. 2, pp.11-28.

Gibb, A.A. (2000) 'SME policy, academic research and the growth of ignorance, mythical concepts, myths, assumptions, rituals and confusions', International Small Business Journal, Vol. 18, No. 3, pp.13-35.

Gibb, A.A. (2005) 'Towards the entrepreneurial university entrepreneurship education as a lever for change', National Council for Graduate Entrepreneurship Policy Paper 3, available at http://www.ncge.org.uk/downloads/policy/Towards_the_Entrepreneurial_University.pdf. 
Granovetter, M. (1973) 'The strength of weak ties', American Journal of Sociology, Vol. 78, pp.1360-1380.

Harding, R. (2005) Global Entrepreneurship Monitor UK 2004 Report, GEM, London.

Harding, R. (2006) Global Entrepreneurship Monitor UK 2005 Report, GEM, London.

Hills, G.E. and Hultman, C. (2005) 'Marketing, entrepreneurship and SMEs: knowledge and education revisited', Proceedings of the 10th Annual Research Symposium of the Academy of Marketing Special Interest Group on Entrepreneurial and SME Marketing, Southampton University.

Horne, M. (2000) Enterprise Learning, Demos and the Academy of Enterprise, London.

Jack, S.A. and Anderson, A.R. (1999) 'Entrepreneurship education within the enterprise culture', International Journal of Entrepreneurial Behaviour \& Research, Vol. 5, No. 3, pp.110-125.

Jobber, D. (2006) Principles and Practices of Marketing, 4th ed., McGraw Hill, Maidenhead.

Johannisson, B. (1992) 'In search of a methodology for entrepreneurship research', Unpublished Draft Circulated at the 7th Research in Entrepreneurship Conference, November.

Johnson, G. and Scholes, K. (2002) Exploring Corporate Strategy, 6th ed., Prentice Hall, Hemel Hempstead.

Keats, R. and Abercrombie, N. (1991) Enterprise Culture, Routledge, London.

Kirby, D. (2003) Entrepreneurship, McGraw Hill, Maidenhead.

Kotler, P. (2003) Marketing Management, Pearson Education, New Jersey, USA.

Lawson, T. (1997) Economics \& Reality, Routledge, London.

Leadbeater, C. and Oakley, K. (1999) The Independents: Britain's New Cultural Entrepreneurs, Demos, London.

Low, M. and MacMillan, I. (1988) 'Entrepreneurship: past research and future challenges’, Journal of Management, Vol. 35, pp.139-161.

Marx, K. (1973) Grundrisse, Penguin, Harmonsworth.

NCGE (2006) National Council for Graduate Entrepreneurship Website, available at http://www.ncge.org.uk/index.php.

NCGE (2005) Nascent Graduate Entrepreneurs, Working Paper Series, National Council for Graduate Entrepreneurship, Birmingham.

Oakey, R. (1994) New Technology-Based Firms in the 1990s, Paul Chapman, London.

Phan, P.H. (2004) 'Entrepreneurship theory: possibilities and future directions', Journal of Business Venturing, Vol. 19, pp.617-620.

Sarasvathy, S. (1999) 'Seminar on research perspectives in entrepreneurship', Journal of Business Venturing, Vol. 15, pp.1-57.

Schaper, M. (2002) 'The essence of ecopreneurship', in M. Schaper (Ed.): Environmental Entrepreneurship: Greener Management International (GMI), Vol. 38, Greenleaf, Sheffield.

Shane, S. (2003) A General Theory of Entrepreneurship: The Individual-Opportunity Nexus, Edward Elgar, Cheltenham.

Shane, S. and Venkataraman, S. (2000) 'The promise of entrepreneurship as a field of research', Academy of Management Review, Vol. 25, No. 1, pp.217-226.

Stevenson, H.H. and Sahlman, W.A. (1989) 'The entrepreneurial process', in P. Burns and J. Dewhurst (Eds.): Small Business and Entrepreneurship, Macmillan, Basingstoke, pp.94-157.

Steyaert, C. and Hjorth, D. (Eds.), (2003) New Movements in Entrepreneurship, Edward Elgar, Cheltenham, Vol. 1, pp.3-20.

Stokes, D. and Wilson, N. (2006) Small Business Management and Entrepreneurship, 5th ed., Thomson, London. 
Stokes, D., Blackburn, R. and Fitchew, S. (1997) Marketing for Small Firms: Towards a Conceptual Understanding, Report to Royal Mail Consulting, July, Small Business Research Centre, Kingston upon Thames: Kingston University.

Stokes, D.R. (2000) 'Entrepreneurial marketing: a conceptualisation from qualitative research', Qualitative Market Research: An International Journal, Vol. 3, No.1, pp.47-54.

Stokes, D.R., Ali Syed, S. and Lomax, W. (2002) 'Shaping up word-of-mouth marketing strategy: the case of an independent health club,' Journal of Research in Marketing and Entrepreneurship, Summer, Vol. 4, Issue 2, pp.119-133.

Storey, D. (1998) Understanding the Small Business, International Thomson Business Press, London.

Venkataraman, S. (1997) 'The distinctive domain of entrepreneurship research: an editor's perspective', in J. Katz and R. Brockhaus (Eds.): Advances in Entrepreneurship, Firm Emergence, and Growth, JAI Press, Greenwich, CT, Vol. 3, pp.119-138.

Vesper, K. (2004) 'Unfinished business (entrepreneurship) of the 20th century', in Welsch, H.P. (Ed.): Entrepreneurship. The Way Ahead, Routledge, London.

Webster, F.E. Jr. (1995) 'The changing role of marketing in the organisation', Journal of Marketing, October, Vol. 56, pp.1-17.

Wilson, N. and Stokes, D. (2005) 'Managing creativity and innovation: the challenge for cultural entrepreneurs', Journal of Small Business and Enterprise Development, Vol. 12, No. 3, pp.366-378.

Zahra, S.A. and Dess, G.G. (2001) 'Entrepreneurship as a field of research: encouraging dialogue and debate', Academy of Management Review, Vol. 26, No. 1, pp.8-10.

\title{
Appendix
}

\author{
The Road Not Taken \\ (Robert Frost, 1874-1963)
}

TWO roads diverged in a yellow wood,

And sorry I could not travel both

And be one traveller, long I stood

And looked down one as far as I could

To where it bent in the undergrowth;

Then took the other, as just as fair,

And having perhaps the better claim,

Because it was grassy and wanted wear;

Though as for that the passing there

Had worn them really about the same,

And both that morning equally lay In leaves no step had trodden black.

Oh, I kept the first for another day!

Yet knowing how way leads on to way,

I doubted if I should ever come back.

I shall be telling this with a sigh

Somewhere ages and ages hence:

Two roads diverged in a wood, and I -

I took the one less travelled by,

And that has made all the difference. 